\title{
Increase in Straight and Coiled Cylindrospermopsis raciborskii (Cyanobacteria) Populations under Conditions of Thermal De-Stratification in a Shallow Tropical Reservoir
}

\author{
Maria do Carmo Bittencourt-Oliveira, ${ }^{1,2^{*}}$, Ariadne do Nascimento Moura ${ }^{3}$, \\ Talita Caroline Hereman ${ }^{1,2}$, Enio Wocyli Dantas ${ }^{3,4}$ \\ ${ }^{1}$ Universidade de São Paulo, ESALQ, Dep. Ciências Biológicas, Av. Pádua Dias, Piracicaba, Brazil \\ ${ }^{2}$ Programa de Pós-Graduação em Ciências Biológicas, Área de Biologia Vegetal, \\ UNESP-Rio Claro, Rio Claro, Brazil \\ ${ }^{3}$ Universidade Federal Rural de Pernambuco, Departamento de Biologia-Área de Botânica, \\ R. Dom Manuel de Medeiros, $\mathrm{s} / n$, Dois Irmãos, Recife, Brazil \\ ${ }^{4}$ Universidade Estadual da Paraíba - UEPB - Campus V, Centro de Ciências Biológicas e Sociais \\ Aplicadas-CCBSA, R. Monsenhor Walfredo Leal, $n^{\circ} 487$, Tambiá, João Pessoa, Brazil \\ E-mail: mbitt@esalq.usp.br
}

\begin{abstract}
In recent decades, there have been frequent occurrences of the cyanobacterium Cylindrospermopsis raciborskii in northeastern Brazil. Little is known regarding the response of straight and coiled morphotypes to environmental conditions such as light intensity and water temperature. Samples were collected at the Mundaú reservoir (PE, Brazil) at six sampling depths in the dry and rainy season. Both morphotypes exhibited seasonal and vertical differences in densities. The reservoir was stratified in the dry season, with a predominance of the straight morphotype. The coiled morphotype exhibited greater densities in the lower strata and prove to be more susceptible to light. There was evident thermal de-stratification in the rainy season, with a predominance of the coiled morphotype in the surface layers. Thermal de-stratification favors an increase in both morphotypes by providing adequate conditions for growth, such as low light intensity and milder temperatures, which are characteristic of the winter season in the northeastern Brazil.
\end{abstract}

Keywords: Cyanophyta, Light, Morphotype, Northeastern Brazil, Mundaú Reservoir

\section{Introduction}

In recent decades, the occurrence of cyanobacterial blooms, such as those of the genera Microcystis Kützing ex Lemmermann, Anabaena Bory ex Bornet \& Flahault and Planktothrix Anagnostidis \& Komárek, have become a common event in different regions of the world and are closely related to eutrophication processes in aquatic ecosystems. The presence of cyanobacterium in freshwater ecossystems are often associated with eutrophic conditions, $\mathrm{CO}_{2}$ availability and high temperatures [1] low luminosity [2], alkaline $\mathrm{pH}$ [3], high concentrations of nutrients, especially phosphorus [4] and a low N:P ra- tio [5], and buoyancy regulation [6]. Such blooms alter the ecological balance of these systems and give an unpleasant taste and smell to the water, thereby elevating treatment costs. However, the greatest problem stems from the fact that some species produce toxins (cyanotoxins) and can cause serious public health problems. These toxins can accumulate in the food chain and produce different symptoms of intoxication.

Cylindrospermopsis raciborskii (Woloszynska) Seenayya et Subba Raju (Ordem Nostocales) is one of the most worrisome bloom-forming species in Brazil due to its extremely invasive nature and increasing occurrence. Initially classified as having pan-tropical distribution [7], C. raciborskii was soon recorded in subtropical environments in Africa and the Americas as well as in 
temperate regions, where it occurs in shallow lakes (for more details see [8]. Massive populations of $C$. raciborskii in a public water supply reservoir are worrisome due to their capacity to produce hepatotoxins (cylindrospermopsin) and neurotoxins (saxitoxins) [9].

C. raciborskii has multiple adaptation strategies, such as resistance to herbivory, tolerance to low light intensity, ability to migrate in the water column due to aerotopes, storage and use of intracellular reserves and the capability of fixing atmospheric nitrogen [10]. Populations with straight and coiled trichomes have been observed occurring simultaneously in different proportions in Australia $[8,11,12]$ and northeastern Brazil $[13,14]$. Although molecular investigations reveal that the straight and coiled morphotypes pertain to the same species [11,15], it is not yet clear how these morphotypes behave in response to environmental conditions such as light intensity and water temperature. In recent decades, the frequent occurrence of $C$. raciborskii in reservoirs and small lakes has been recorded in different states of Brazil, especially in the northeastern region of the country [13,16-21].

In stratified lakes, populations may reach peak density in the epilimnion. With the data available in the literature, however, it is not possible to generalize on vertical movements or depths with light intensities that are more adequate to the growth of this species [22].

Considering the scarcity of studies on populations with straight and coiled trichomes that occur simultaneously in their natural environment as well as the need for information on the behavior of these populations in nature, the aim of the present study was to determine the spatial and seasonal dynamics of these C. raciborskii morphotypes in relation to light intensity and temperature in the water column of a shallow eutrophic tropical reservoir.

\section{Materials and Methods}

\subsection{Study Site}

The Mundaú reservoir is located in the city of Garanhuns $\left(8^{\circ} 55^{\prime} 40^{\prime \prime} \mathrm{S}\right.$ to $\left(8^{\circ} 57^{\prime} 04^{\prime \prime} \mathrm{S}\right.$ and $36^{\circ} 30^{\prime} 40^{\prime \prime} \mathrm{W}$ to $\left.36^{\circ} 29^{\prime} 02^{\prime \prime} \mathrm{W}\right) 716 \mathrm{~m}$ above sea level in the state of Pernambuco (northeastern Brazil) (Figure 1). The reservoir has a water accumulation capacity of approximately $1968600 \mathrm{~m}^{3}$, surface are of $4 \mathrm{~km}^{2}$ and mean deepness around $11 \mathrm{~m}$. Its main purpose is to supply the public drinking water, but it receives part the residential sewage of the city [23]. The reservoir has $\mathrm{pH}$ ranging from alkaline to neutral, with a high availability of phosphorus and limited nitrogen [24]. The geographical region is characterized by high temperatures and dry periods, especially between October and March (summer); the winter (April to September) is characterized by greater precipitation and milder temperatures.

\subsection{Site and Periods of Samplings and Community Study '}

Spatial and seasonal variations in the population density of the straight and coiled C. raciborskii morphotypes were determined from collections made at a single sampling site located near the central pelagic region of the reservoir $\left(8^{\circ} 56^{\prime} 40^{\prime \prime} \mathrm{S}\right.$ and $\left.36^{\circ} 29^{\prime} 26.2^{\prime \prime} \mathrm{W}\right)$ at six sampling depths (surface, $0.5 \mathrm{~m}, 1.0 \mathrm{~m}, 2.0 \mathrm{~m}, 5.0 \mathrm{~m}$ and $10.0 \mathrm{~m}$ ) during the dry (October, 06 and November, 06/2004) and rainy seasons (August, 17 and September, 21/2004; June, 07 and August, 20/2005), only one sampling for each month. Maximal depth at this site varied according to the season (dry-10 m or rainy-12 m), with a mean of $11 \mathrm{~m}$ during our study.

Throughout the water column, samples were collected with a van Dorn bottle and subsequently fixed in 5\% acetic Lugol solution for quantitative analysis. Trichome counts were performed directly with the use of a Fuchs-Rosenthal chamber and a binocular optical microscope (Nikon, Japan). Whenever possible, a minimal number of 450 trichomes were counted for each morphotype in order to obtain a 5\% error and $95 \%$ level of confidence [25]. Morphological analysis involved measurements of the length and width of the vegetative cells $(n=1800)$, heterocysts $(n=450)$ and number of cells per trichome $(n=600)$ in both morphotypes, with the aid of a micrometered ocular coupled to the microscope.

\subsection{Abiotic Analyses}

Air temperature was measured with a common mercure thermometer and water temperature was obtained using an YSI field probe (model 556). Depth (m) was determined with a bathymeter (Garmin, Fishfinder 100). Light intensity was accessed using a photometer (LICOR, model LI-250) with an underwater cable and spherical sensor. Precipitation during the sampling months was obtained from the National Meteorology Institute in the city of Caruaru [26].

\subsection{Statistical Methods}

The normality of the data was tested for the choice of analyses of variance and correlation. Analysis of variance (ANOVA, 5\% level of significance) was used with normal data to determine the occurrence of seasonal and vertical variations. Spearman's correlation coefficient 


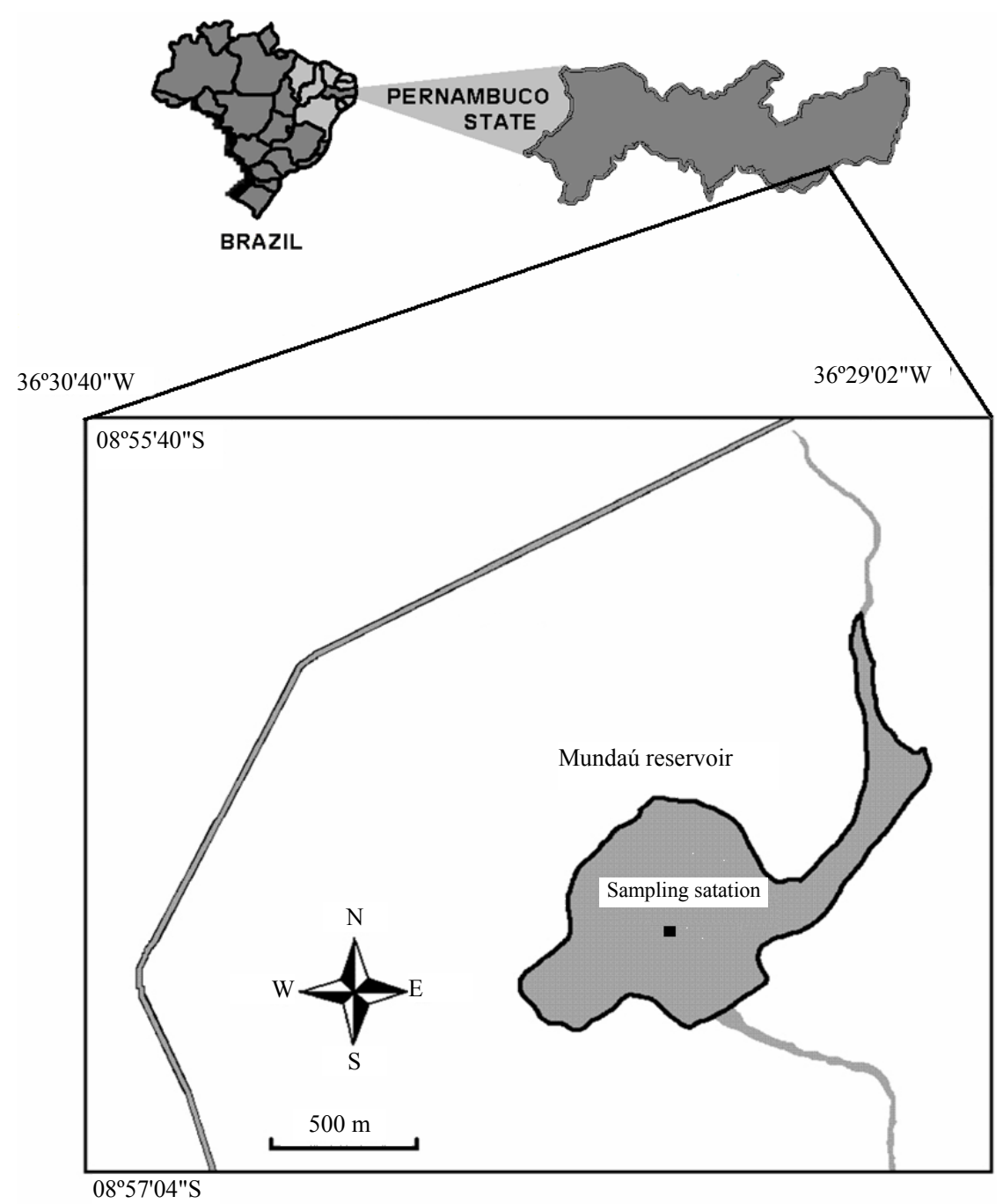

Figure 1. Map of study area; Mundaú reservoir, PE, northeastern Brazil.

(rs) was used to determine associations between abiotic variables and morphotype density. Tukey test was used to analyze temporal differences. The Statistica 2004 program (StatSoft, Inc., Tulsa, OK, USA) was employed for all analyses.

\section{Results}

During the study period, mean monthly air temperature ranged from 21.6 to $23.1^{\circ} \mathrm{C}$ in the rainy season and from 23.1 to $29.1^{\circ} \mathrm{C}$ in the dry season. Figures 2 and $\mathbf{3}$ display underwater light intensity, water temperature, straight and coiled trichome density and precipitation.

Water temperature exhibited significant seasonal differences $(F=20832, p<0.001)$. October/04 and November/04, months of dry season, show statistical differences of rainy months (Tukey, $p<0.05$ ). The water column was uniformity in October and November 2004, in these months no significant difference was found for light intensity (Figures 3(a), (b)).

During the months sampled, single-species blooms of C. raciborskii (straight and coiled morphotypes) comp osed the entire phytoplankton community, which is common in this body of water.

Both morphotypes exhibited seasonal and vertical differences in density $\left(F_{\text {straight }}=5.232 ; F_{\text {coiled }}=10.894\right.$, $p<0.001$ and $F_{\text {straight }}=5.579 ; F_{\text {coiled }}=9.913, p<0.001$, respectively). Greater densities occurred in the rainy season $\left(5.3\right.$ and $4.3 \times 10^{7}$ trichomes $\mathrm{mL}^{-1}$ or 2.7 and 2.4 $\times 10^{9}$ cell $\mathrm{mL}^{-1}$ for straight and spiraled morphotypes, respectively, data not shown). There was a predominance of straight trichomes when light intensity was above $8 \mu \mathrm{mol} \mathrm{m}{ }^{-2} \cdot \mathrm{s}^{-1}$ and temperature was above $24^{\circ} \mathrm{C}$. The coiled morphotype had greater densities in this same light intensity range but with the temperature below 24 ${ }^{\circ} \mathrm{C}$. There was a tendency toward the predominance 


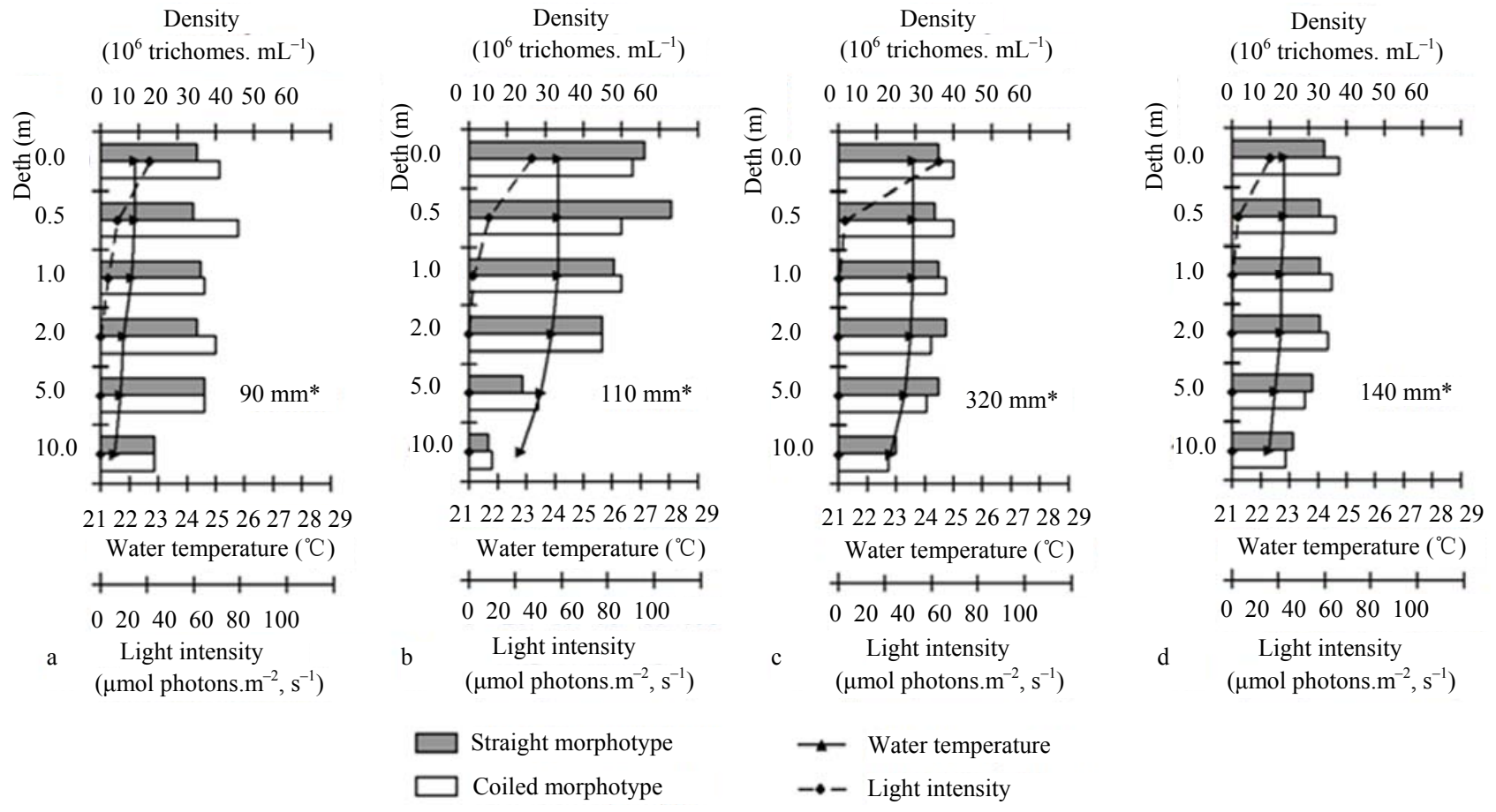

Figure 2. Vertical variation in trichome density of straight and coiled $C$. raciborskii morphotypes in relation to water temperature and underwater light intensity at the Mundaú reservoir in the rainy season; (a) August, 17/2004; (b) September, 21/2004; (c) June,07/2005; (d) August, 20/2005; * accumulated monthly rainfall.
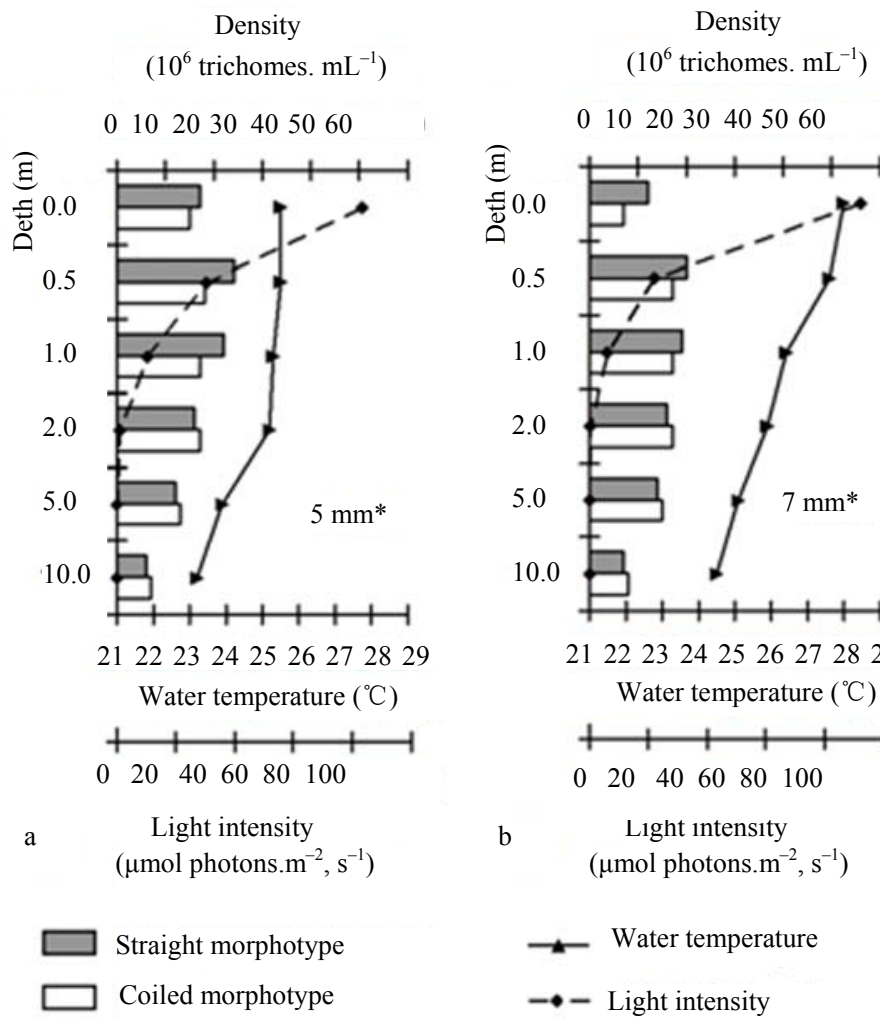

Figure 3. Vertical variation in trichome density of straight and coiled C. raciborskii morphotypes in relation to water temperature and underwater light intensity at the Mundaú reservoir in the dry season (a) October, 06/2004; (b) November, 06/2004; * accumulated monthly rainfall. 

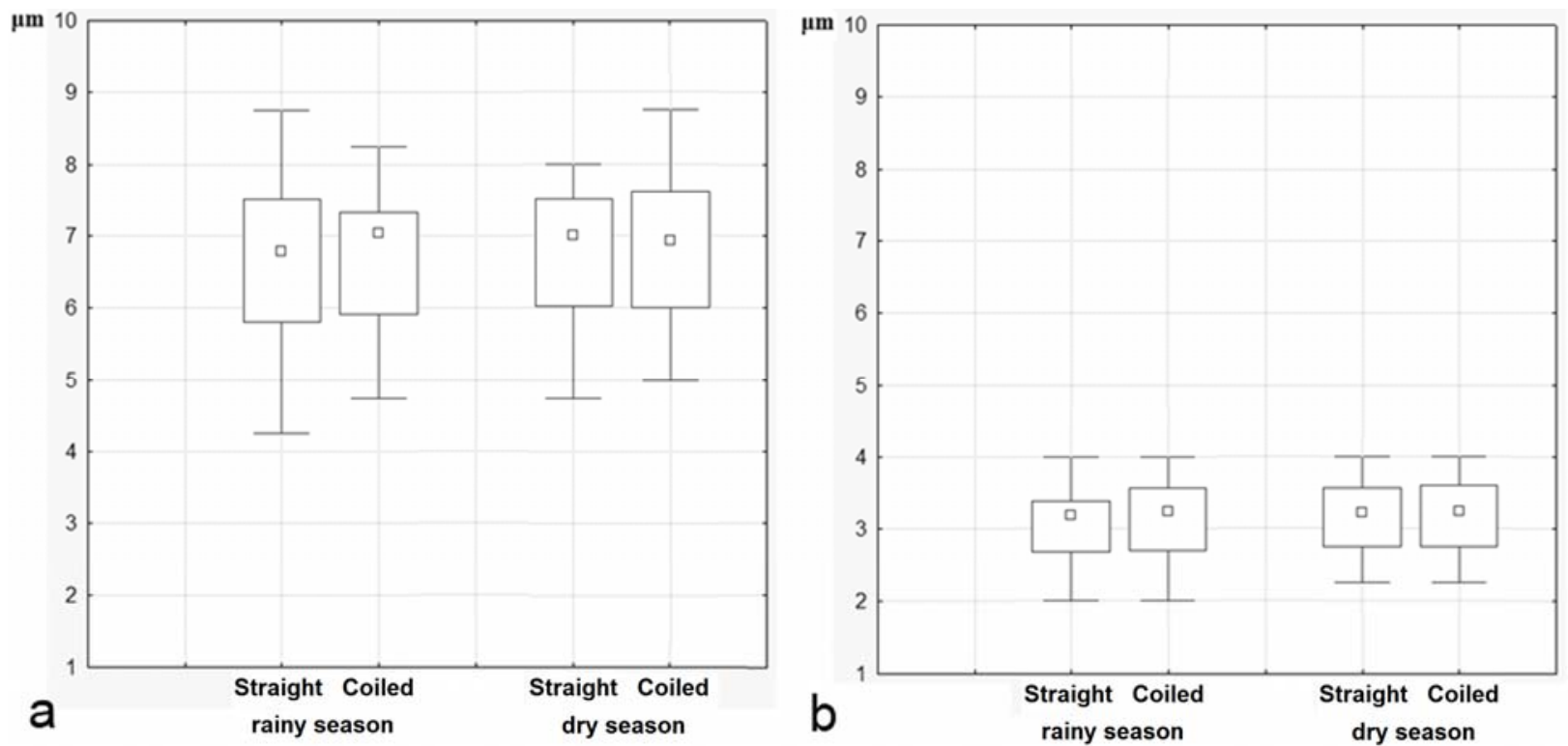

Figure 4. Variation in vegetative cell size, mean and standard deviation values for straight and coiled Cylindrospermopsis raciborskii morphotypes during rainy and dry season (a. length, b. width).

of coiled trichomes when light intensity was below 3 $\mu \mathrm{mol} \mathrm{m} \mathrm{m}^{-2} \cdot \mathrm{s}^{-1}$. The straight morphotype exhibited a greater number of trichomes with heterocysts in comparison to the coiled morphotype, which were only found in October and November 2004 (dry season) and in September 2004 (rainy season)( data not shown).

An analysis of the data on C. raciborskii between different sampling depths and months reveals that the densities of both morphotypes had a positive correlation with light intensity $\left(r s_{\text {straight }}=0.372\right.$ and $r s_{\text {coiled }}=0.399, p$ $<0.001$ ). Both morphotypes also had a negative correlation with depth $\left(r s_{\text {straight }}=-0.486\right.$ and $r s_{\text {coiled }}=-$ $0.557, p<0.001$ ) .

The Mundaú reservoir was stratified in the dry season, with higher temperatures and greater light intensity in the surface layers (down to $1 \mathrm{~m}$ ) and a predominance of the straight morphotype. In the lower strata, the coiled morphotype exhibited greater densities, but with no significant differences. The straight morphotype population was tolerated to high light intensity (83.23 to 92.26 $\mu \mathrm{mol} \mathrm{m} \mathrm{m}^{-2} \cdot \mathrm{s}^{-1}$ ) and temperatures $\left(25.5\right.$ to $28.0{ }^{\circ} \mathrm{C}$ ), whereas the coiled morphotype was proved as more susceptible to light intensity. The existence of strata with different water densities may facilitate the permanence of the coiled morphotype population in the lower layers of the water column, which is more adequate to its development.

In the rainy season (winter), the reservoir remained shallow (10 to $12 \mathrm{~m}$ ), with evident thermal destratification. Variations in temperature were lesser than those found in the summer months and there was low light intensity throughout the water column, with an extreme reduction in light below the surface layers. The general pattern of the populations under these conditions was a predominance of the coiled morphotype at higher depths (to $1 \mathrm{~m}$ ), with the exception of September 2004, and there was a balance between the morphotypes at greater depths, with a slight predominance alternating between the two morphotypes. The coiled morphotype population developed well under conditions of low light intensity and milder temperatures, which are characteristics commonly found in the winter months.

The mean length and width of the vegetative cells were similar in both morphotypes, regardless of the season and with no differences beyond the shape of the trichome. In the straight morphotype, vegetative cells measured 6.14 to $6.92 \mu \mathrm{m}$ in length and 2.68 to $3.03 \mu \mathrm{m}$ in width. In the coiled morphotype, vegetative cells measured 6.46 to $7.03 \mu \mathrm{m}$ in length and 2.68 to $3.12 \mu \mathrm{m}$ in width (Figure 4). In straight morphotype the heterocysts measured 6.73 to $7.09 \mu \mathrm{m}$ in length and 2.79 to $3.01 \mu \mathrm{m}$ in width; the number of cells per trichome was 47 to 56 and in the coiled morphotype the heterocysts measured 6.79 to $7.02 \mu \mathrm{m}$ in length and 2.84 to $3.02 \mu \mathrm{m}$ in width and the number of cells per trichome was 49 to 59 .

\section{Discussion}

According to [27], populations of cyanobacteria exhibit considerable growth under conditions of high temperature, low N:P ratio and alkaline $\mathrm{pH}$. However, the dominance of one species or another depends on its particular characteristics, survival strategy, nutritional 
requirements and need for light. During the study period, the Mundaú reservoir exhibited environmental characteristics that allowed the occurrence of high densities of $C$. raciborskii, such as high concentrations of phosphorus, high temperature (above $21^{\circ} \mathrm{C}$ ) and availability of light in the epilimnion, but with an accentuated drop in the metalimnion and hypolimnion.

In northeastern Brazil, the summer months are characterized by low rainfall and high temperatures, whereas rains occur during the winter months, accompanied by a slight drop in temperature and lesser light intensity. The highest density values were reached in the rainy season due to the increase in the concentration of nutrients carried by the rain as well as the circulation of the mass of water, which stirs up the sediment and suspends nutrients in the water column. Among the rainy months, September had the greatest densities of both the coiled and straight $C$. raciborskii morphotypes. This was perhaps due to the higher temperatures $\left(22.8\right.$ to $\left.24.1^{\circ} \mathrm{C}\right)$ in comparison to other months in the rainy season. However, there was a more uniform distribution of the C. raciborskii populations at the different depths in the other months of this season (August 2004; August and July 2005); at a depth of 10 meters trichome density was more than double that found in September 2004. This difference at greater depths in this month as well as the concentration of populations in more surface layers ( 0 to 2 meters) may have been influenced by the tendency toward stratification that occurred in September.

According to [11], there is a clear difference in growth rate between the two C. raciborskii morphotypes in response to variations in temperature and light intensity. The coiled morphotype tends to grow more quickly under different environmental conditions than the straight form due to its tolerance to high temperature and low light intensity. It is believed to favor the dominance of the coiled over the straight morphotype in tropical ecosystems. However, the results observed in the Mundaú reservoir contradict these findings. On the other hand, the results are in agreement with a study by [28], who compared the growth of the straight and coiled $C$. raciborskii morphotypes under controlled light and temperature conditions; the straight morphotype was more tolerant to higher luminosity and temperature, which led to faster growth rates, whereas the coiled morphotype always exhibited slower growth, even at lower temperatures and lesser luminosity; at high temperatures and luminosity, the coiled population did not develop well.

No akinetes were found in any other months sampled, even when there were variations in temperature between the rainy and dry seasons. In a shallow lake in France,
[29] found that the occurrence of C. raciborski blooms depended mainly on climatic factors such as air temperature, water temperature and light intensity. This confirms the observations made by [30] that temperatures between $22{ }^{\circ} \mathrm{C}$ and $23.5^{\circ} \mathrm{C}$ favor the germination of akinetes. The lack of akinetes in the present study suggests the occurrence of factors favorable to the maintenance of the trichomes throughout the entire study period, as these cells develop under adverse environmental conditions.

Monitoring a small, shallow reservoir (Solomon Dam, Australia), [31] found that stable stratification conditions during dry periods were favorable to the expansion of C. raciborskii populations. In the Mundaú reservoir, the uniformity in the temperature of the water column and low luminosity associated to the drowning effect promoted greater population development when compared to months in which thermal stratification occurred. Thermal de-stratification in the rainy season favored the increase in the populations of both $C$. raciborskii morphotypes by providing more adequate conditions for their growth, namely, lesser light intensity and milder temperatures, which are characteristics of the winter months in the hinterland region of the state of Pernambuco in northeastern Brazil.

The species Cylindrospermopsis raciborskii persisted under a variety of temperature and light conditions, demonstrating adaptability to environmental variables, which has also been reported for other regions in the world. Due to the potential toxicity stemming from the occurrence of high densities of this species, there is an accentuated need for monitoring water quality in this reservoir.

\section{Acknowledgements}

This study was supported by grants from $\mathrm{CNPq}$ (Brazilian Council for Research and DevelopmentMCBO: 300794/2004-5) and FAPESP (State of São Paulo Research Foundation - MCBO: 2006/03878-6).

\section{References}

[1] J. Shapiro, "Current Beliefs Regarding Dominance b Blue Greens: The Case for the Importance of $\mathrm{CO}_{2}$ and $\mathrm{pH}$," Verhandlungen des Internationalen Verein Limnologie, Vol. 24, 1990, pp. 38-54.

[2] A. Niklisch and J. G. Kohl, “The Influence of Light on the Primary Production of Two Planktic Blue-Green Algae," Archiv für Hydrobiologie, Ergebnisse der Limnologie, Vol. 33, 1989, pp. 451-455.

[3] C. S. Reynolds and A. E. Walsby, "Water-Blooms," Biology Reviews, Vol. 50, 1975, pp. 437-481. doi:10.1111/j.1469-185X.1975.tb01060.x 
[4] S. B. Watson, E. Mccauley and J. A. Downing, "Patterns in Phytoplankton Taxonomic Composition across TempErate Lakes of Differing Nutrient Status," Limnology and Oceanography, Vol. 42, 1997, pp. 487-549. doi:10.4319/10.1997.42.3.0487

[5] V. H. Smith, "Low Nitrogen to Phosphorus Ratios Favor Dominance by Blue-Green Algae in Lake Phytoplankton," Science, Vol. 221, No. 4611, 1983, pp. 669-670. doi:10.1126/science.221.4611.669

[6] A. E. Walsby, P. K. Hayes, R. Boje and L. J. Stal, "The Selective Advantage of Buoyancy Provided by Gas Vesicles for Planktonic Cyanobacteria in the Baltic Sea," New Phytology, Vol. 136, 1997, pp. 407-417. doi:10.1046/j.1469-8137.1997.00754.x

[7] L. Hoffmann, "Geographic Distribution of Freshwater Bluegreen Algae," Hydrobiologia, Vol. 336, 1996, pp. 33-40. doi:10.1007/BF00010817

[8] J. Padisák, "Cylindrospermopsis Raciborskii (Woloszynska) Seenayya et Subba Raju, an Expanding, Highly Adaptative Cyanobacterium: Worldwide Distribution and Review of Its Ecology," Archiv für Hydrobiologie, Vol. 107, 1997, pp. 563-593.

[9] I. Chorus and J. Bartram, "Toxic Cyanobacteria in Water: A guide to the Public Health Consequences," Monitoring and Management. E \& FN Spon, London, 1999. doi: $10.4324 / 9780203478073$

[10] R. E. Ogawa and N. G. Carr, "The Influence of Nitrogen on Heterocyst Production in Blue-Green Algae," Limnology and Oceanography, Vol. 14, 1969, pp. 342351. doi:10.4319/10.1969.14.3.0342

[11] M. L. Saker, B. A. Neilan and D. J. Griffiths, "Two Morphological Forms of Cylindrospermopsis Raciborskii (Cyanobacteria) Isolated from Solomon Dam, Palm Island, Queensland," Journal of Phycology, Vol. 35, No. 3, 1999, pp. 599-606. doi:10.1046/j.1529-8817.1999.3530599.x

[12] G. B. McGregor and L. D. Fabbro, "Dominance of CylIndrospermopsis Raciborskii (Nostocales, CyanoprokarYota) in Queensland Tropical and Subtropical Reservoirs: Implications for Monitoring and Management," Lake and reservoir management, Vol. 5, 2000, pp. 195-205. doi:10.1046/j.1440-1770.2000.00115.x

[13] M. Bouvy, R. Molica, S. Oliveira, M. Marinho and B. Beker, "Dynamics of A Toxic Cyanobacterial Bloom (Cylindrospermopsis Raciborskii) in a Shallow Reservoir in the Semi-Arid Region of Northeast Brazil," Aquatic Microbial Ecology, Vol. 20, 1999, pp. 285-297. doi: $10.3354 / \mathrm{ame} 020285$

[14] A. C. S. Ferreira, "Dinâmica do fitoplâncton de um reservatório hipereutrófico (reservatório Tapacurá, Recife, PE), com ênfase em Cylindrospermopsis raciborskii e seus morfotipos. Tese de mestrado em Ciências Biológicas (Botânica)," Museu Nacional, Universidade Federal do Rio de Janeiro, Rio de Janeiro, 2002.

[15] K. M. Wilson, M. A. Schembri, P. D. Baker and C. P. Saint, "Molecular Characterization of Toxic Cyanobac-
Terium Cylindrospermopsis Raciborskii and Design of a Species-Specific PCR," Applied and Environmental Microbiology, Vol. 66, No. 1, 2000, pp. 332-338. doi:10.1128/AEM.66.1.332-338.2000

[16] M. Bouvy, D. Falcão, M. Marinho, M. Pagano and A. Moura, "Occurrence of Cylindrospermopsis (CyanobacTeria) in 39 Brazilian Tropical Reservoirs during the 1998 Drought," Aquatic Microbial Ecology, Vol. 23, No. 1, 2000, pp. 13-27. doi:10.3354/ame023013

[17] I. A. S. Costa, S. M. F. O. Azevedo, P. A. C. Senna, R. R. Bernardo, S. M. Costa and N. T. Chellappa, "Occurrence of Toxin-Producing Cyanobacteria Blooms in a Brazilian Semiarid Reservoir," Brazilian Journal of Biology, Vol. 66, No. 1B, 2006, pp. 211-219.

[18] R. Panosso, I. A. S. Costa, N. R. Souza, J. L. Attayde, S. R. S.Cunha and F. C. F. Gomes, "Cianobactérias e cianotoxinas em reservatórios do estado do Rio Grande do Norte e o potencial controle das florações pela tilápia do Nilo (Oreochromis niloticus)", Oecologia Brasiliensis, Vol. 11, No. 3, 2007, pp. 433-449. doi: $10.4257 /$ oeco.2007.1103.12

[19] N. T. Chellappa, S. L. Chellappa and S. Chellappa, "Harmful Phytoplankton Blooms and Fish Mortality in a Eutrophicated Reservoir of Northeast Brazil," Brazilian Archives of Biology and Technology, Vol. 51, No. 4, 2008a, pp. 833-841.

[20] N. T. Chellappa, J. M. Borba and O. Rocha, "PhytOplankton Community and Physical-Chemical CharacTeristics of Water in the Public Reservoir of Cruzeta, Rn, Brazil," Brazilian Journal of Biology, Vol. 68, No. 3, 2008b, pp. 477-494.

[21] E. V. von Sperling, A. C. S. Ferreira and L. N. L. Gomes, "Comparative Eutrophication Development in Two Brazilian Water Supply Reservoirs with Respect to Nutrient Concentrations and Bacteria Growth," Desalination, Vol. 226, 2008, pp. 169-174.

doi:10.1016/j.desal.2007.02.105

[22] L. D. Fabbro and L. J. Duivenvoorden, " Profile of a Bloom of the Cyanobacterium Cylindrospermopsis Raciborskii (Woloszynska) Seenaya and Subba Raju in the Fitzroy River in Tropical Central Queensland," Marine and Freshwater Research, Vol. 47, 1996, pp. 685-694. doi:10.1071/MF9960685

[23] Secretaria de Recursos Hídricos de Pernambuco (SRH), "Plano estadual de recursos hídricos do estado de Pernambuco," Documento síntese, Recife, 2000, p. 267.

[24] E. W. Dantas, A. N. Moura, M. C. Bittencourt-Oliveira, J. D. T. Arruda-Neto and A. D. C. Cavalcanti, "Temporal Variation of the Phytoplankton Community at Short Sampling Intervals in the Mundaú Reservoir, Northeastern Brazil," Acta Botanica Brasilica, Vol. 22, No. 4, 2008, pp. 970-982.

[25] R. R. L. Guillard, "Division Rates,” In: J. R. Stein, Ed., Handbook of Phycological Methods: Culture Methods and Growth Measurement, Cambridge University Press, London, 1973, pp. 2289-2311.

[26] INMET, "Instituto Nacional de Meteorologia. Parâmetros meteorológicos," Disponível em, www.inmet. 
gov.com. Acessado em agosto de 2005.

[27] M. Dokulil and K. Teubner, "Cyanobacterial Dominance in Lakes," Hydrobiologia, Vol. 438, No. 1-3, 2000, pp. 112. doi:10.1023/A:1004155810302

[28] B. Buch, "Ecofisiologia de morfotipos reto e espiralado de Cylindrospermopsis raciborskii (Cyanobacteria) em condições controladas," Tese em Ciências Biológicas (Biologia Vegetal), Instituto de Biociências, Universidade Estadual Paulista Júlio de Mesquita Filho, São Paulo, 2009.

[29] J. F. Briand, C. Robillot, C. Quiblier-Llobéras, J. F. Humbert, A. Couté and C. Bernard, "Environmental
Context of Cylindrospermopsis Raciborskii (CyanobacTeria) Blooms in a Shallow Pond in France," Water Research, Vol. 36, No. 3, 2002, pp. 3183-3192. doi:10.1016/S0043-1354(02)00016-7

[30] G. Gorzó, "Fizikai és kémiai faktorok hatása a Balatonban elõforduló heterocisztás cianobaktériumok spóráinak csírázására," Hidrológiai Közlöny, Vol. 67, 1987, pp. 127-133.

[31] P. R. Hawkins and D. J. Griffiths, "Artificial DestratiFication of a Small Tropical Reservoir: Effects Upon the Phytoplankton," Hydrobiologia, Vol. 254, 1993, pp. 69181. doi:10.1007/BF00014111 